\title{
The Effect of Phytoplasma Disease Caused by 'Candidatus Phytoplasma prunorum' on the Phenological and Pomological Traits in Apricot Trees
}

\author{
Tomáš NEČAS ${ }^{1 *}$, Tomáš KISS ${ }^{1}$, Aleš EICHMEIER ${ }^{2}$, \\ Jana NEČASOVÁ ${ }^{1}$, Ivo ONDRÁŠEK ${ }^{1}$
}

\author{
${ }^{1}$ Mendel University in Brno, Faculty of Horticulture in Lednice, Department of Fruit Growing, Valtická 337, Lednice 69144, Czech Republic; \\ necast@zf.mendelu.cz_(" correspondingauthor);tomas.kiss@mendelu.cz;jana.necasova.dzf@mendelu.cz; ivo.ondrasek@mendelu.cz \\ ${ }^{2}$ Mendel University in Brno, Faculty of Horticulture in Lednice, Mendeleum - Department of Genetics, \\ Valtická 337, Lednice 69144, Czech Republic; aleseichmeier@gmail.com
}

\begin{abstract}
'Candidatus Phytoplasma prunorum', the causal agent of European stone fruit yellows (ESFY), is one of the most important pathogens causing considerable economic losses in stone fruit orchards. This study evaluated trees infected and noninfected by phytoplasma ESFY of 16 apricot varieties grown in an orchard in Lednice (Czech Republic) between the years 2008-2014. Pomological traits, phenophases, pollen germination and seed viability were analysed as well as the presence of ' $\mathrm{Ca}$. P. prunorum' in pollen, flower organs, fruit flesh, immature seeds and seedlings by nested PCR. One of the most detrimental impacts was the decreased fruit set of infected trees which occurred in 12 out of 16 studied varieties reaching an average fruit set decrease of $16.1 \%$. Pollen germination rates also suffered, showing an average decrease by $11.78 \%$ in infected trees. In the analysis of some traits, overall significant differences were observed between the infected and noninfected trees. However, for all analysed traits in different varieties, both positive and negative influences of phytoplasma ESFY were observed. The presence of ' $\mathrm{Ca}$. P. prunorum' in infected trees was confirmed in flower parts (only in peduncle in $70.2 \%$ of cases) and fruit parts (immature fruit flesh in $42.0 \%$ and milky kernels in $26.2 \%$ of cases), however, neither in seedlings nor in pollen.
\end{abstract}

Keywords: biological traits, ESFY, Prunus armeniaca, PCR stone fruit, symptoms

\section{Introduction}

European stone fruit yellows (ESFY) phytoplasma ('Candidatus Phytoplasma prunorum') is an important agent of premature death of apricot trees (Gazel et al., 2009). Since the beginning of the research of this economically dangerous phytoplasma (Morvan, 1977), many studies have been carried out focusing on optimising its detection (Seemüller, 1976; Lee et al., 1991; Ahrens et al., 1992; Gibb et al., 1994; Bertaccini et al., 2004), on understanding of possibile ways of its transmission (Carraro et al., 1998; Jarausch et al., 1998; Jarausch et al., 1999; Pastore et al., 2001; Thébaud et al., 2009) and on the phytoplasma genome characteristics (Ahrens et al., 1993; Schneider et al., 1995; Lee et al., 1998; Marcone et al., 2001; Seemüller et al., 2004). The risk factors of phytoplasma ESFY occurrence in different regions and orchards were assessed by Thébaud et al. (2006), as well as by Ulubaş et al. (2007) who reported the differences in ESFY phytoplasma occurrence in extensive and intensive orchards, when in the extensive orchard, the ESFY phytoplasma was detected in $54.8 \%$ of the analysed samples, while in the intensive orchard the ESFY phytoplasma was detected in only $3.2 \%$ of analysed samples.

Except from work of Gazel et al. (2009), where the influence of phytoplasma ESFY on quantitative fruit traits, such as fruit size, titratable acidity, and total soluble solids content was studied out, detailed research on ESFY phytoplasma influence on qualitative and quantitative pomological traits of apricots has not been carried out. On the other hand, the level of influence on pomological traits and symptom manifestation might also depend on the sensitivity of individual Prunus variety to phytoplasma ESFY (Jarausch, et al., 2000; Kison et al., 2001; Carraro et al., 2002; Nečas et al., 2015). Yet, the impact of the variety on both qualitative and quantitative traits of infected trees has not been studied. Although preliminary results were published in a previous study by Nečas et al. (2008), there is no description of the pathogen occurrence in the various organs of the fruit trees. 
108

This study is focused on the impact of the phytoplasma ESFY infection on selected phenological and pomological traits of apricot trees with an emphasis on the variety ands on detection of the phytoplasma in certain tree organs, which has not been studied up to date in any scientific paper.

\section{Materials and Methods}

\section{Biologicalmaterial}

One noninfected and one ESFY phytoplasma naturally infected tree from each of 16 apricot varieties (Table 1) grown in the experimental apricot orchard in Lednice (South Moravian region, Czech Republic) was evaluated for all the tests each year during the years 2008 and 2014.

The evaluated trees were grafted on apricot seedling rootstocks. The experimental orchard was approximately 15 years old and grown in a free standing dwarf open vase training system with tree spacing of $3 \times 6$ metres. All the evaluated trees were tested for the presence of viruses: ACLSV, PNRSV, PDV, ApMV and PPV using DAS ELISA. Only virus-free trees were used for the experiment. Phytoplasma ESFY detection was provided by nested PCR from the DNA extracted from phloem of two-year-old shoots using a protocol by Ahrens et al. (1992) (methods described below in the Phytoplasma Detection in Flower Organs, Fruit Flesh, Seeds and in Seedling Parts) in all noninfected and infected trees every year to avoid possible influence in later phytoplasma ESFY infection of noninfected trees. The following traits to study the impact of phytoplasma ESFY infection were assessed:

- Pollen germination as a factor affecting fruit yield.

- Seed viability as a factor affecting seed germination and production of generative rootstocks.

- Pomological fruit traits as a factor affecting fruit quality and economy of trade.

- Phenophases as a factor affecting the agrotechnology in apricot production.

- Presence of the phytoplasma in pollen, flower organs, fruit flesh, seeds and seedling parts by nested PCR

\section{Pollen germination}

Every year, shoots of each tested tree were cut before blooming and placed into buckets of water in a laboratory at room temperature until blooming. When the flowers opened and the anthers cracked, each flower was brushed on a sieve and the pollen was allowed to fall onto a Petri dish. Collected pollen was placed into plastic tubes and stored at -15 to $-20^{\circ} \mathrm{C}$ at constant low relative humidity. The pollen germination was defined based on the methodology by Vachůn and Rezníček (1989) immediately after the pollen was collected from all tested trees. Pollen was placed on the Petri dishes with solid $0.5 \%$ agar medium containing $10.0 \%$ of sucrose, covered and incubated at $20^{\circ} \mathrm{C}$. The germination was evaluated after three hours of incubation where one hundred pollen grains were assessed under microscope. Only germinating grains were defined as viable.

\section{Seed viability}

The seed viability test was carried out based on the tetrazolium method by Lakon et al. (1949). A total of at least 15 kernels from each tested tree were evaluated every year immediately after the collection of ripen fruits. Kernels without testa were incubated at $30{ }^{\circ} \mathrm{C}$ for $18-20$ hours in $1 \%$ solution of 2, 3, 5-trifenyltetrazolium chloride (TTC). By the principle of this test, the TTC dyes living kernel cells red (formazan is formed), while non-viable cells remain undyed (Fig. 1).

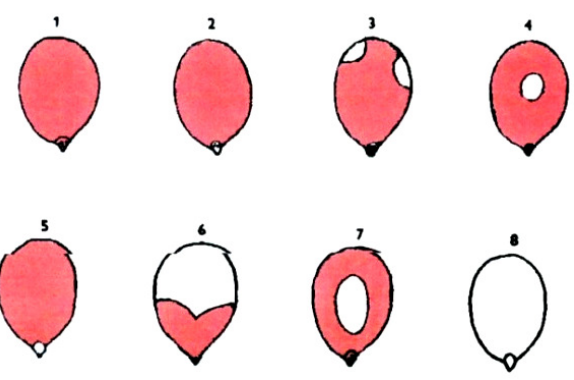

Fig. 1. Viable and non-viable seed kernels for genus Prunus evaluated by TTC test based on Lakon et al. (1949), (1, 2, 3, 4 - viable seeds; 5, 6, 7, 8 - non-viable seeds)

Table 1. Tested varieties and observed symptoms of phytoplasma ESFY on infected trees

\begin{tabular}{|c|c|c|}
\hline Tested varieties & Recorded symptoms in phytoplasma ESFY positive trees & Varieties origin \\
\hline 'Arzami Aromatnyj' & chlorotic leafroll, growth depression, gradual dieback of branches & Ukraine \\
\hline 'Bergeron' & premature sprouting of leaves, growth depression & France \\
\hline 'Hargrand' & chlorotic leafroll, growth depression & Canada \\
\hline 'Hatif Colomer' & yellowing of leaves & France \\
\hline 'Churmai' & chlorotic leafroll, growth depression & Unknown \\
\hline 'Lemeda' & without symptoms - latent infections & Czech Republic \\
\hline ‘Marlen’ & weak yellowing of leaves & Czech Republic \\
\hline 'Murfatlar' & chlorotic leafroll & Romania \\
\hline 'Olimp’ & yellowing of leaves & Ukraine \\
\hline 'Palava' & without symptoms - latent infections & Czech Republic \\
\hline ‘Poljus Južnyj’ & leafroll & Ukraine \\
\hline 'Saldcot' & chlorotic leafroll, growth depression, late flowering & Canada \\
\hline 'Svatava' & without symptoms - latent infections & Czech Republic \\
\hline 'Vardaguin Vagaas' & weak yellowing of leaves & Armenia \\
\hline 'Veselka' & growth depression, premature leaf fall of fruits & Slovakia \\
\hline 'Vestar’ & without symptoms - latent infections & Slovakia \\
\hline
\end{tabular}




\section{Pomological traits of fruits and evaluation of phenophases}

For yearly for evaluation of pomological traits at least 15 random fruits from each tested tree were used. The pomological traits, namely: fruit set, kernel weight, fruit and seed weight and dimensions (height, width and thickness) were evaluated according to the standardised "descriptor list" for Prunus armeniaca Mill. by Nitranský (1992). The fruit set was evaluated after the June fruit drop according to a 1 to 9 grading system $(1=$ no fruits, $9=$ maximum set). From measured fruit dimensions, the fruit shape index was calculated based on a methodology by Tanaka et al. (1995) to determine the effect of phytoplasma on the fruit deformation. Finally, the soluble solids content (in \%) of fruits was determined using KRÜSS AR4D refractometer.

Furthermore, the following phenophases were evaluated on each tested tree every year: start of blooming and fruit ripening, based on the methodology of Nitranský (1992), where the value of the phenophase was the number of days elapsed from January $1^{\text {st }}$ of the year of observation.

\section{ESFY phytoplasma detection in flower organs, fruit flesh,} seeds and in seedling parts

For DNA extraction, only infected trees of 12 varieties ('Arzami Arom.', 'Bergeron', 'Churmai', 'Hargrand', 'Hatif Col.', 'Marlen', 'Murfatlar', 'Palava', 'Poljus Juž.', 'Saldcot', 'Veselka', 'Vestar') were used. Every year from each infected tree 0.1-0.5 g of flower organs (separately peduncle, stamen and pistil) from unopened flowers, flesh from 15 immature fruits pooled into one sample as well as from 15 seeds (soft milky kernels) and 15 seedling parts (separately cotyledons and young sprout) were collected.

DNA extraction was carried out using the phytoplasma enrichment procedure based on Ahrens et al. (1992) methodology. Obtained DNA was dissolved in $50 \mu \mathrm{l}$ of TE buffer and stored at $-80^{\circ} \mathrm{C}$. Only the pollen DNA was extracted by DNeasy Plant Mini Kit (Qiagen) where the DNA was dissolved again in $50 \mu \mathrm{l}$ of TE buffer and stored at $-80^{\circ} \mathrm{C}$.

Universal primer pair P1/P7 (Deng et al., 1991; Schneider et al., 1995) was used for PCR amplification and specific primers fO1/rO1 (Lorenz et al., 1995) for Apple Proliferation group phytoplasma detection were used for subsequent nested PCR amplification. Each amplification reaction of a volume of $20 \mu \mathrm{l}$ consisted of $0.25 \mu \mathrm{M}$ of each respective primer, $1 \mathrm{U}$ of DyNAzyme II polymerase (Finnzymes), 1× DyNAzyme II buffer (Finnzymes) containing $1.5 \mathrm{mM} \mathrm{MgCl}, 100 \mu \mathrm{M}$ of dNTP's, $2 \mu \mathrm{l}$ of DNA and sterile distilled water. For subsequent nested PCR, $2 \mathrm{ul}$ of PCR reaction from the first PCR run was used instead of $2 \mathrm{ul}$ of DNA. Thermal programs of both PCR amplification procedures consisted of initial denaturation for 2 minutes at $95^{\circ} \mathrm{C}, 35$ cycles of following steps: 30 seconds of denaturation at $95^{\circ} \mathrm{C}, 75$ seconds of annealing at $52{ }^{\circ} \mathrm{C}$ and 90 seconds of extension at $72^{\circ} \mathrm{C}$ with a final extension for 5 minutes at $72{ }^{\circ} \mathrm{C}$. Nested PCR products were separated by electrophoresis in $1 \%$ agarose gel stained with Gelred (Biotium) and visualized by transilluminator. The identification of the phytoplasma was performed by PCR/RFLP of fO1/rO1 products with restriction enzymes BsaAI and SspI (Thermo Scientific) based on the methodology by Sertkaya et al. (2005).
Statistical analysis

For statistical analysis, the values from the whole period of evaluation of infected and noninfected trees of each variety were separately analysed using two-way analysis of variance (ANOVA) on the level of significance $>95 \%$ and Tukey LSD test. One-way analysis of variance (ANOVA) on the level of significance $>95 \%$ and Tukey LSD test was used for aggregated values of all infected and all noninfected trees regardless on the variety, to obtain results not influenced by the variety. Statistical analyses were carried out in Statistica 10 software.

\section{Results}

\section{Pollen germination}

Values of pollen germination between infected (47.04\%), and noninfected (58.82\%) trees were significantly different.

Except from varieties 'Bergeron' and 'Lemeda', in all varieties was pollen germination of infected trees lower than of noninfected trees (Table 2). Significant difference was observed only at the variety 'Marlen', where the difference of pollen germination between infected (65.75\%) and noninfected (21\%) tree was $44.75 \%$.

Although the pollen germination of infected trees was higher in varieties 'Bergeron' and 'Lemeda', the differences (by $0.75 \%$ and $1.62 \%$, respectively) were very low compared to the differences (from $3.58 \%$ to $44.75 \%$ ) of varieties, where the infected trees had lower pollen germination than noninfected trees.

\section{Seed viability}

Values of seed viability between infected (79.56\%) and noninfected $(79.85 \%)$ trees were not significantly different.

From Table 2 it is obvious that the results of seed viability between infected and noninfected trees of each variety are not consistent, ranging from significantly higher seed viability of infected trees, e.g. by $24.44 \%$ at variety 'Vardaguin Vag.', to significantly lower seed viability of infected trees, e.g. by $32.43 \%$ at variety 'Veselka' when compared to noninfected trees of respective varieties.

\section{Phenophases}

Blooming Time

The difference between blooming time of noninfected (92.06 days) and infected (93.38 days) trees was nonsignificant (Table 2).

The highest difference was observed at variety 'Saldcot', where the infected tree started to bloom on average 7.4 days later than the noninfected tree. Exceptions were varieties 'Arzami Arom.' and 'Bergeron' where the infected trees started to bloom on the contrary, 2.4 and 2 days, respectively, earlier than noninfected trees.

\section{Ripening time}

The difference in ripening time between infected (175.29 days) and noninfected (174.36 days) trees was not significant.

Among varieties, significant as well as non-significant differences between noninfected and infected trees were reported. Significant differences were observed at the varieties 'Hatif Col.' and 'Vardaguin Vag.' where the fruits 
Table 2. Results of phenophases, qualitative pomological traits and pollen germination and seed viability of phytoplasma ESFY infected and noninfected apricot trees. ${ }^{*}$ Statistically significant difference (ANOVA, significance level $\left.>95 \%\right) ;{ }^{* *}$ statistically high significant difference (ANOVA, significance level >99\%); (+) measured value is higher at the noninfected tree; $(-)$ measured value is higher at the infected tree; (+/-) measured values of the infected and noninfected trees are the same

\begin{tabular}{|c|c|c|c|c|c|c|c|c|c|c|c|c|c|c|c|}
\hline \multirow{2}{*}{$\begin{array}{c}\text { Varieties } \\
\text { 'Arzami } \\
\text { Aromatny' }\end{array}$} & \multirow{2}{*}{$\begin{array}{c}\text { Noninfected/ } \\
\text { Infected trees }\end{array}$} & \multicolumn{2}{|c|}{ Blooming time } & \multicolumn{2}{|c|}{ Fruit ripening } & \multicolumn{2}{|c|}{ Fruit set } & \multicolumn{2}{|c|}{$\begin{array}{l}\text { Index of fruit } \\
\text { shape }\end{array}$} & \multicolumn{2}{|c|}{$\begin{array}{c}\text { Soluble solids } \\
\text { content }(\%)\end{array}$} & \multicolumn{2}{|c|}{ Pollen germination (\%) } & \multicolumn{2}{|c|}{$\begin{array}{l}\text { Seed viability } \\
(\%)\end{array}$} \\
\hline & & $\begin{array}{l}95.7 \\
93.3\end{array}$ & $(+)$ & $\begin{array}{l}202.7 \\
195.7\end{array}$ & $(+)$ & $\begin{array}{l}7.5 \\
3.0\end{array}$ & $(+)^{* *}$ & $\begin{array}{l}1.01 \\
1.04\end{array}$ & $(-)^{* *}$ & $\begin{array}{l}15.2 \\
18.9\end{array}$ & $(-)^{* *}$ & $\begin{array}{l}57.9 \\
41.4\end{array}$ & $(+)$ & $\begin{array}{l}85.6 \\
87.5\end{array}$ & $(-)$ \\
\hline 'Bergeron' & $\begin{array}{c}\text { noninfected } \\
\text { infected }\end{array}$ & $\begin{array}{l}93.0 \\
91.0\end{array}$ & $(+)$ & $\begin{array}{l}206.0 \\
203.0\end{array}$ & $(+)$ & $\begin{array}{l}9.0 \\
3.0\end{array}$ & $(+)^{*}$ & $\begin{array}{l}1.06 \\
1.01\end{array}$ & $(+)^{*}$ & $\begin{array}{l}13.2 \\
11.9\end{array}$ & $(+)$ & $\begin{array}{l}36.8 \\
37.5\end{array}$ & $(-)$ & $\begin{array}{l}63.4 \\
80.0\end{array}$ & $(-)$ \\
\hline 'Hargrand' & $\begin{array}{l}\text { noninfected } \\
\text { infected }\end{array}$ & $\begin{array}{l}94.3 \\
95.7\end{array}$ & $(-)$ & $\begin{array}{l}131.3 \\
137.0\end{array}$ & $(-)$ & $\begin{array}{l}6.0 \\
3.0\end{array}$ & $(+)^{*}$ & $\begin{array}{l}1.00 \\
0.99\end{array}$ & $(+)$ & $\begin{array}{l}10.6 \\
14.0\end{array}$ & $(-)^{* *}$ & $\begin{array}{l}57.9 \\
54.3\end{array}$ & $(+)$ & $\begin{array}{l}70.5 \\
86.9\end{array}$ & $(-)^{*}$ \\
\hline $\begin{array}{l}\text { 'Hatif } \\
\text { Colomer' }\end{array}$ & $\begin{array}{l}\text { noninfected } \\
\text { infected }\end{array}$ & $\begin{array}{l}90.3 \\
90.3\end{array}$ & $(+/-)$ & $\begin{array}{l}190.6 \\
194.0\end{array}$ & $(-)^{*}$ & $\begin{array}{l}7.0 \\
4.5\end{array}$ & $(+)$ & $\begin{array}{l}0.97 \\
0.93\end{array}$ & $(+)^{* *}$ & $\begin{array}{l}13.5 \\
12.1\end{array}$ & $(+)^{*}$ & $\begin{array}{l}60.3 \\
42.5\end{array}$ & $(+)$ & $\begin{array}{l}80.0 \\
77.8\end{array}$ & $(+)$ \\
\hline 'Churmai' & $\begin{array}{l}\text { noninfected } \\
\text { infected }\end{array}$ & $\begin{array}{l}92.0 \\
94.3\end{array}$ & $(-)$ & $\begin{array}{l}198.7 \\
197.3\end{array}$ & $(+)$ & $\begin{array}{l}3.0 \\
2.0\end{array}$ & $(+)$ & $\begin{array}{l}0.86 \\
0.86\end{array}$ & $\begin{array}{c}(+/- \\
)\end{array}$ & $\begin{array}{l}11.6 \\
12.1\end{array}$ & $(-)$ & $\begin{array}{l}76.7 \\
52.2\end{array}$ & $(+)$ & $\begin{array}{l}80.0 \\
61.7\end{array}$ & $(+)$ \\
\hline 'Lemeda' & $\begin{array}{l}\text { noninfected } \\
\text { infected }\end{array}$ & $\begin{array}{l}89.0 \\
91.0\end{array}$ & $(-)$ & $\begin{array}{l}186.0 \\
184.0\end{array}$ & $(+)$ & $\begin{array}{l}7.0 \\
9.0\end{array}$ & $(-)$ & $\begin{array}{l}0.99 \\
0.97\end{array}$ & $(+)$ & $\begin{array}{l}10.3 \\
12.4\end{array}$ & $(-)^{*}$ & $\begin{array}{l}43.9 \\
45.5\end{array}$ & $(-)$ & $\begin{array}{l}83.4 \\
90.0\end{array}$ & $(-)$ \\
\hline 'Marlen' & $\begin{array}{l}\text { noninfected } \\
\text { infected }\end{array}$ & $\begin{array}{l}90.0 \\
91.5\end{array}$ & $(-)$ & $\begin{array}{l}198.0 \\
196.0\end{array}$ & $(+)$ & $\begin{array}{l}5.0 \\
3.0\end{array}$ & $(+)$ & $\begin{array}{l}1.13 \\
1.01\end{array}$ & $(+)^{* *}$ & $\begin{array}{l}12.0 \\
12.1\end{array}$ & $(-)$ & $\begin{array}{l}65.8 \\
21.0\end{array}$ & $(+)^{*}$ & $\begin{array}{l}86.7 \\
86.7\end{array}$ & $(+/-)$ \\
\hline 'Murfatlar' & $\begin{array}{l}\text { noninfected } \\
\text { infected }\end{array}$ & $\begin{array}{l}96.0 \\
96.7\end{array}$ & $(-)$ & $\begin{array}{l}190.5 \\
201.3\end{array}$ & $(-)$ & $\begin{array}{l}6.0 \\
6.0\end{array}$ & $\begin{array}{c}(+/- \\
)\end{array}$ & $\begin{array}{l}0.97 \\
0.96\end{array}$ & $(+)$ & $\begin{array}{l}13.8 \\
16.0\end{array}$ & $(-)^{* *}$ & $\begin{array}{l}87.0 \\
76.0\end{array}$ & $(+)$ & $\begin{array}{l}83.3 \\
64.6\end{array}$ & $(+)$ \\
\hline 'Olimp’ & $\begin{array}{l}\text { noninfected } \\
\text { infected }\end{array}$ & $\begin{array}{l}93.0 \\
95.7\end{array}$ & $(-)$ & $\begin{array}{l}127.7 \\
127.0\end{array}$ & $(+)$ & $\begin{array}{l}5.0 \\
4.0\end{array}$ & $(+)$ & $\begin{array}{l}0.93 \\
0.90\end{array}$ & $(+)$ & $\begin{array}{l}13.5 \\
13.8\end{array}$ & $(+)$ & $\begin{array}{l}55.4 \\
44.3\end{array}$ & $(+)$ & $\begin{array}{l}90.0 \\
88.9\end{array}$ & $(+)$ \\
\hline 'Palava' & $\begin{array}{l}\text { noninfected } \\
\text { infected }\end{array}$ & $\begin{array}{l}89.0 \\
90.5\end{array}$ & $(-)$ & $\begin{array}{l}184.0 \\
188.0\end{array}$ & $(-)$ & $\begin{array}{l}5.0 \\
9.0\end{array}$ & $(-)$ & $\begin{array}{l}1.04 \\
1.06\end{array}$ & $(-)$ & $\begin{array}{l}11.5 \\
12.0\end{array}$ & $(-)$ & $\begin{array}{l}47.3 \\
38.9\end{array}$ & $(+)$ & $\begin{array}{l}80.0 \\
83.4\end{array}$ & $(-)$ \\
\hline 'Poljus Južnyj' & $\begin{array}{l}\text { noninfected } \\
\text { infected }\end{array}$ & $\begin{array}{l}92.7 \\
96.7\end{array}$ & $(-)$ & $\begin{array}{l}194.7 \\
196.3\end{array}$ & $(-)$ & $\begin{array}{l}7.0 \\
4.0\end{array}$ & $(+)^{*}$ & $\begin{array}{l}0.93 \\
0.89\end{array}$ & $(+)^{* *}$ & $\begin{array}{l}19.7 \\
16.8\end{array}$ & $(+)^{* *}$ & $\begin{array}{l}46.2 \\
38.1\end{array}$ & $(+)$ & $\begin{array}{l}82.5 \\
75.8\end{array}$ & $(+)$ \\
\hline 'Saldcot' & $\begin{array}{c}\text { noninfected } \\
\text { infected }\end{array}$ & $\begin{array}{l}89.3 \\
96.7\end{array}$ & $(-)$ & $\begin{array}{l}199.0 \\
206.0\end{array}$ & $(-)$ & $\begin{array}{l}5.5 \\
4.0\end{array}$ & $(+)$ & $\begin{array}{l}0.99 \\
0.95\end{array}$ & $(+)^{* *}$ & $\begin{array}{l}14.1 \\
14.6\end{array}$ & $(-)$ & $\begin{array}{l}66.0 \\
43.7\end{array}$ & $(+)$ & $\begin{array}{l}83.3 \\
85.3\end{array}$ & $(-)$ \\
\hline 'Svatava' & $\begin{array}{l}\text { noninfected } \\
\text { infected }\end{array}$ & $\begin{array}{l}90.0 \\
90.3\end{array}$ & $(-)$ & $\begin{array}{l}199.0 \\
197.0\end{array}$ & $(+)$ & $\begin{array}{l}5.0 \\
7.0\end{array}$ & $(-)$ & $\begin{array}{l}1.07 \\
1.06\end{array}$ & $(+)$ & $\begin{array}{l}19.2 \\
14.1\end{array}$ & $(+)^{* *}$ & $\begin{array}{l}45.0 \\
22.1\end{array}$ & $(+)$ & $\begin{array}{l}73.4 \\
76.7\end{array}$ & $(-)$ \\
\hline $\begin{array}{l}\text { 'Vardaguin } \\
\text { Vag.' }\end{array}$ & $\begin{array}{c}\text { noninfected } \\
\text { infected }\end{array}$ & $\begin{array}{l}92.7 \\
92.7\end{array}$ & $(+/-)$ & $\begin{array}{l}119.7 \\
120.0\end{array}$ & $(-)^{* *}$ & $\begin{array}{l}5.0 \\
3.0\end{array}$ & $(+)$ & $\begin{array}{l}0.90 \\
0.90\end{array}$ & $\begin{array}{c}(+/- \\
)\end{array}$ & $\begin{array}{l}12.0 \\
12.7\end{array}$ & $(-)$ & $\begin{array}{l}70.3 \\
46.9\end{array}$ & $(+)$ & $\begin{array}{l}67.8 \\
92.2\end{array}$ & $(-)^{*}$ \\
\hline 'Veselka' & $\begin{array}{l}\text { noninfected } \\
\text { infected }\end{array}$ & $\begin{array}{l}93.0 \\
94.0\end{array}$ & $(-)$ & $\begin{array}{l}120.3 \\
122.7\end{array}$ & $(-)$ & $\begin{array}{l}5.2 \\
5.0\end{array}$ & $(+)$ & $\begin{array}{l}1.00 \\
0.95\end{array}$ & $(+)^{*}$ & $\begin{array}{l}13.8 \\
14.8\end{array}$ & $(-)$ & $\begin{array}{l}68.0 \\
48.2\end{array}$ & $(+)$ & $\begin{array}{l}81.3 \\
48.9\end{array}$ & $(+)^{*}$ \\
\hline 'Vestar' & $\begin{array}{l}\text { noninfected } \\
\text { infected }\end{array}$ & $\begin{array}{l}93.0 \\
93.7\end{array}$ & $(-)$ & $\begin{array}{l}141.7 \\
139.3\end{array}$ & $(+)^{* *}$ & $\begin{array}{l}6.0 \\
6.0\end{array}$ & $\stackrel{(+/-}{)}$ & $\begin{array}{l}1.03 \\
1.00\end{array}$ & $(+)^{*}$ & $\begin{array}{l}13.4 \\
11.1\end{array}$ & $(+)^{* *}$ & $\begin{array}{l}56.8 \\
51.7\end{array}$ & $(+)$ & $\begin{array}{l}86.7 \\
86.7\end{array}$ & $(+)$ \\
\hline $\begin{array}{l}\text { Average } \\
\text { value }\end{array}$ & $\begin{array}{l}\text { noninfected } \\
\text { infected }\end{array}$ & $\begin{array}{l}92.1 \\
93.4\end{array}$ & $(-)$ & $\begin{array}{l}174.4 \\
175.3\end{array}$ & $(-)$ & $\begin{array}{l}6.2 \\
5.0\end{array}$ & $(+)^{* *}$ & $\begin{array}{l}0.99 \\
0.97\end{array}$ & $(+)^{* *}$ & $\begin{array}{l}13.6 \\
13.7\end{array}$ & $(-)^{*}$ & $\begin{array}{l}58.8 \\
47.0\end{array}$ & $(+)^{* *}$ & $\begin{array}{l}79.9 \\
79.6\end{array}$ & $(+)$ \\
\hline
\end{tabular}

from infected trees ripened on average by 3.4 and 0.33 days, respectively, later than noninfected trees and at variety 'Vestar' where the fruits of infected tree ripened on average by 2.34 days, on contrary, earlier than of noninfected trees. The influence of phytoplasma ESFY to shift of ripening time both ways, earlier or later, than at noninfected trees is obvious from Table 2, where infected trees of 8 evaluated varieties ripened earlier (from 0.67 to 7 days) and 8 varieties later (from 0.33 to 10.83 days) than noninfected trees.

\section{Fruit set}

The average fruit set of the infected trees gave the value of 5 , while at noninfected trees the average fruit set value was 6.2, resulting in statistically significant difference between infected and noninfected trees (Table 2).

The ESFY phytoplasma infected trees had lower fruit set in most of the varieties, however were not, except for the varieties 'Arzami Arom.', 'Bergeron' and 'Poljus Juž.', significantly different from the fruit set of noninfected trees. Again, opposite effect of phytoplasma ESFY infection was observed at varieties 'Lemeda', 'Palava' and 'Svatava', where infected trees had higher fruit set than noninfected trees.

\section{Pomological traits}

\section{Weight of the fruit, stone and kernel}

The differences in fruit, stone and kernel weight between noninfected and infected trees were only $4.16 \mathrm{~g}$, $0.14 \mathrm{~g}$ and $0.05 \mathrm{~g}$ respectively, showing non-significant differences in the case of fruit and stone weight and significant difference in the case of kernel weight (Table 3).

Significant differences between infected and noninfected trees in all analysed weights were calculated at the varieties 'Arzami Arom.', 'Hargrand', 'Hatif Col.', 'Veselka' and 'Vestar'. Significant differences between infected and noninfected trees were calculated in 2 out of 3 analysed weights at the varieties 'Bergeron', 'Hargrand' and 'Olimp' and only in the fruit weight at the varieties 'Marlen' and 'Murfatlar'.

All the measured weights at varieties 'Arzami Arom.', 'Hargrand', 'Hatif Col.', 'Marlen', 'Veselka' and 'Vestar' were either significantly or non-significantly lower at infected trees, whereas at the varieties 'Bergeron', 'Murfatlar' and 'Olimp' all the measured weights were on the contrary, significantly or non-significantly higher at infected trees, when compared with noninfected trees.

\section{Height, width and thickness of the fruit}

The differences between the fruit height, width and thickness between infected and noninfected trees $(0.52 \mathrm{~mm}$, $1.86 \mathrm{~mm}$ and $1.59 \mathrm{~mm}$ respectively) were statistically significant only in the case of fruit width (Table 3).

In the case of varieties 'Arzami Arom.', 'Hatif Col.', 'Veselka' and 'Vestar' and 'Murfatlar' significant differences between infected and noninfected trees in all measured dimensions were calculated. Significant differences between infected and noninfected trees were observed also at varieties 'Bergeron' and 'Marlen' in 2 out of 3 measured dimensions and at varieties 'Hargrand', 'Poljus Juž.' and 'Marlen' in 1 out of 3 measured dimensions. However again, positive as well as negative effects of phytoplasma ESFY were observed in the measured dimensions, where infected trees of varieties 'Arzami Arom.', 'Hargrand', 'Hatif Col.', 'Marlen', 'Saldcot', 'Veselka' and 'Vestar' had overall smaller fruits, whereas the infected trees of varieties 'Bergeron', 
'Lemeda', 'Murfatlar', 'Poljus Juž.', 'Svatava' and 'Vardaguin Vag.' had overall bigger fruits than noninfected trees of respective varieties.

\section{Height, width and thickness of the stone}

The differences between the average stone height, width and thickness between infected and noninfected trees $(0.03$ $\mathrm{mm}, 0.45 \mathrm{~mm}$ and $0.39 \mathrm{~mm}$, respectively) were statistically significant only in the case of the stone width (Table 3 ).

In the case of varieties 'Arzami Arom.', 'Hargrand', 'Hatif Col.', 'Olimp', 'Veselka' and 'Vestar' significant differences between infected and noninfected trees in all measured dimensions were calculated. Significant differences between infected and noninfected trees were observed also at varieties 'Bergeron' and 'Poljus Juž.' in 2 out of 3 measured dimensions and at varieties 'Lemeda', 'Murfatlar', 'Palava', 'Saldcot' and 'Svatava' in 1 out of 3 measured dimensions. As in other analysed traits, positive as well as negative effects of phytoplasma ESFY were observed in the measured dimensions. Infected trees of varieties 'Arzami Arom.', 'Hargrand', 'Hatif Col.', 'Lemeda', 'Vardaguin Vag.', Veselka and 'Vestar' had overall smaller stones, whereas the infected trees of varieties 'Bergeron', 'Murfatlar', 'Olimp' and 'Palava' had overall bigger stones than noninfected trees.

\section{Fruit shape index}

A statistically significant difference in the fruit shape of infected and noninfected trees was calculated. Mean fruit shape index of fruits from infected trees reached the value of 0.97, meaning flatter shape, whereas the mean fruit shape index of fruits from noninfected trees was 0.99, meaning elongated shape (Table 3).

Significant differences between the fruit shape index of infected and noninfected trees were observed at the following varieties: 'Arzami Arom.', 'Bergeron', Hatif Col., 'Marlen', 'Poljus Juž., 'Saldcot', 'Veselka' and 'Vestar'. The variety 'Marlen', which belongs to the apricot group of varieties known as the Hungarian Best, showed the highest difference of 0.12 of the fruit shape index.

\section{Refractometric determination of soluble solids content}

The difference of the average fruit soluble solids content between infected (13.72\%) and noninfected (13.58\%) trees was $0.14 \%$, showing significant difference (Table 2 ).

Varieties 'Arzami Arom.', 'Hargrand', 'Hatif Col.', 'Lemeda', 'Murfatlar', 'Poljus Juž., 'Svatava' and 'Vestar' showed statistically significant differences, where fruits of infected trees of 'Arzami Arom.', 'Hargrand', 'Lemeda' and 'Murfatlar' varieties had significantly lower content of soluble solids than of noninfected trees, while at varieties 'Hatif Col.', 'Poljus Juž.', 'Svatava' and 'Vestar' the infection had opposite effect.

ESFY phytoplasma detection in flower organs, fruit flesh, seeds and in seedling parts

The phytoplasma was detected only in peduncle in a total of $70.2 \%$ of samples, in $42 \%$ of fruit flesh samples and in $26.2 \%$ of milky kernel samples (Table 4). However, ESFY was not detected in any of the DNA samples from pistil and stamen, nor in the pollen and not even in the cotyledons and young sprouts of the seedlings.

Table 3. Results of quantitative pomological traits of phytoplasma ESFY infected and noninfected apricot trees. ${ }^{*}$ statistically significant difference (ANOVA, significance level >95\%); ${ }^{* *}$ statistically high significant difference (ANOVA, significance level >99\%); (+) measured value is higher at the noninfected tree; $(-)$ measured value is higher at the infected tree; $(+/-)$ measured values of the infected and noninfected trees are the same

\begin{tabular}{|c|c|c|c|c|c|c|c|c|c|c|c|c|c|c|c|c|c|c|c|}
\hline \multirow{2}{*}{$\begin{array}{c}\text { Varieties } \\
\text { 'Arzami } \\
\text { Aromatny' }\end{array}$} & \multirow{2}{*}{$\begin{array}{c}\begin{array}{c}\text { Noninfected } \\
/ \text { Infected } \\
\text { trees }\end{array} \\
\begin{array}{c}\text { noninfected } \\
\text { infected }\end{array}\end{array}$} & \multicolumn{2}{|c|}{$\begin{array}{l}\text { Fruit weight } \\
\text { (g) }\end{array}$} & \multicolumn{2}{|c|}{$\begin{array}{l}\text { Stone weight } \\
\text { (g) }\end{array}$} & \multicolumn{2}{|c|}{$\begin{array}{l}\text { Kernel weight } \\
(\mathrm{g})\end{array}$} & \multicolumn{2}{|c|}{$\begin{array}{l}\text { Fruit height } \\
(\mathrm{mm})\end{array}$} & \multicolumn{2}{|c|}{$\begin{array}{l}\text { Stone height } \\
\quad(\mathrm{mm})\end{array}$} & \multicolumn{2}{|c|}{$\begin{array}{l}\text { Fruit width } \\
\quad(\mathrm{mm})\end{array}$} & \multicolumn{2}{|c|}{$\begin{array}{l}\text { Stone width } \\
\quad(\mathrm{mm})\end{array}$} & \multicolumn{2}{|c|}{$\begin{array}{c}\text { Fruit } \\
\text { thickness } \\
(\mathrm{mm})\end{array}$} & \multicolumn{2}{|c|}{$\begin{array}{l}\text { Stone thickness } \\
\quad(\mathrm{mm})\end{array}$} \\
\hline & & $\begin{array}{l}36.5 \\
16.8\end{array}$ & $(+)^{* *}$ & $\begin{array}{l}3.3 \\
1.8\end{array}$ & $(+)^{* *}$ & $\begin{array}{l}1.02 \\
0.54\end{array}$ & $(+)^{* *}$ & $\begin{array}{l}40.1 \\
29.1\end{array}$ & $(+)^{* *}$ & $\begin{array}{l}26.4 \\
21.2\end{array}$ & $(+)^{* *}$ & $\begin{array}{l}40.4 \\
30.1\end{array}$ & $(+)^{* *}$ & $\begin{array}{l}21.9 \\
17.0\end{array}$ & $(+)^{* *}$ & $\begin{array}{l}38.2 \\
27.9\end{array}$ & $(+)^{* *}$ & $\begin{array}{c}2.0 \\
9.4\end{array}$ & $(+)^{* *}$ \\
\hline 'Bergeron' & $\begin{array}{c}\text { noninfected } \\
\text { infected }\end{array}$ & $\begin{array}{l}64.6 \\
73.6\end{array}$ & $(-)^{*}$ & $\begin{array}{l}2.8 \\
3.9\end{array}$ & $(-)^{* *}$ & $\begin{array}{l}0.78 \\
0.93\end{array}$ & $(-)$ & $\begin{array}{l}43.4 \\
51.9\end{array}$ & $(-)^{* *}$ & $\begin{array}{l}26.1 \\
30.2\end{array}$ & $(-)^{* *}$ & $\begin{array}{l}49.0 \\
52.3\end{array}$ & $(-)^{*}$ & $\begin{array}{l}19.0 \\
23.0\end{array}$ & $(-)^{* *}$ & $\begin{array}{l}48.3 \\
51.2\end{array}$ & $(-)$ & $\begin{array}{l}10.9 \\
11.4\end{array}$ & $(-)$ \\
\hline 'Hargrand' & $\begin{array}{l}\text { noninfected } \\
\text { infected }\end{array}$ & $\begin{array}{l}53.1 \\
46.9\end{array}$ & $(+)^{* *}$ & $\begin{array}{l}3.1 \\
2.9\end{array}$ & $(+)$ & $\begin{array}{l}0.88 \\
0.78\end{array}$ & $(+)^{* *}$ & $\begin{array}{l}43.8 \\
42.5\end{array}$ & $(+)$ & $\begin{array}{l}25.8 \\
24.8\end{array}$ & $(+)^{* *}$ & $\begin{array}{l}43.7 \\
41.9\end{array}$ & $(+)^{*}$ & $\begin{array}{l}20.0 \\
18.9\end{array}$ & $(+)^{* *}$ & $\begin{array}{l}42.4 \\
41.3\end{array}$ & $(+)$ & $\begin{array}{l}12.9 \\
12.4\end{array}$ & $(+)^{*}$ \\
\hline 'HatifColomer' & $\begin{array}{l}\text { noninfected } \\
\text { infected }\end{array}$ & $\begin{array}{l}35.4 \\
19.4\end{array}$ & $(+)^{* *}$ & $\begin{array}{l}2.6 \\
1.9\end{array}$ & $(+)^{* *}$ & $\begin{array}{l}0.81 \\
0.61\end{array}$ & $(+)^{* *}$ & $\begin{array}{l}41.0 \\
34.5\end{array}$ & $(+)^{* *}$ & $\begin{array}{l}25.0 \\
22.7\end{array}$ & $(+)^{* *}$ & $\begin{array}{l}39.8 \\
31.5\end{array}$ & $(+)^{* *}$ & $\begin{array}{l}20.3 \\
17.8\end{array}$ & $(+)^{* *}$ & $\begin{array}{l}37.0 \\
30.8\end{array}$ & $(+)^{* *}$ & $\begin{array}{l}11.1 \\
10.2\end{array}$ & $(+)^{* *}$ \\
\hline 'Churmai' & $\begin{array}{l}\text { noninfected } \\
\text { infected }\end{array}$ & $\begin{array}{l}34.9 \\
34.4\end{array}$ & $(+)$ & $\begin{array}{l}3.2 \\
3.3\end{array}$ & $(-)$ & $\begin{array}{l}0.90 \\
0.86\end{array}$ & $(+)$ & $\begin{array}{l}44.3 \\
44.4\end{array}$ & $(-)$ & $\begin{array}{l}30.8 \\
30.9\end{array}$ & $(-)$ & $\begin{array}{l}38.0 \\
38.0\end{array}$ & $(+)$ & $\begin{array}{l}20.9 \\
20.9\end{array}$ & $(+)$ & $\begin{array}{l}36.6 \\
37.1\end{array}$ & $(-)$ & $\begin{array}{l}11.3 \\
11.5\end{array}$ & $(-)$ \\
\hline 'Lemeda' & $\begin{array}{c}\text { noninfected } \\
\text { infected }\end{array}$ & $\begin{array}{l}35.4 \\
38.2\end{array}$ & $(-)$ & $\begin{array}{l}1.9 \\
1.8\end{array}$ & $(+)$ & $\begin{array}{l}0.59 \\
0.57\end{array}$ & $(+)$ & $\begin{array}{l}39.3 \\
42.2\end{array}$ & $(-)$ & $\begin{array}{l}23.3 \\
22.4\end{array}$ & $(+)$ & $\begin{array}{l}38.8 \\
41.0\end{array}$ & $(-)$ & $\begin{array}{l}17.1 \\
15.6\end{array}$ & $(+)^{*}$ & $\begin{array}{l}37.4 \\
38.1\end{array}$ & $(-)$ & $\begin{array}{l}9.7 \\
8.9\end{array}$ & $(+)$ \\
\hline 'Marlen' & $\begin{array}{l}\text { noninfected } \\
\text { infected }\end{array}$ & $\begin{array}{l}50.9 \\
40.0\end{array}$ & $(+)^{*}$ & $\begin{array}{l}3.0 \\
2.8\end{array}$ & $(+)$ & $\begin{array}{l}0.87 \\
0.74\end{array}$ & $(+)$ & $\begin{array}{l}41.9 \\
41.1\end{array}$ & $(+)$ & $\begin{array}{l}26.2 \\
26.7\end{array}$ & $(-)$ & $\begin{array}{l}47.3 \\
41.4\end{array}$ & $(+)^{* *}$ & $\begin{array}{l}21.1 \\
20.5\end{array}$ & $(+)$ & $\begin{array}{l}44.7 \\
39.9\end{array}$ & $(+)^{* *}$ & $\begin{array}{l}11.6 \\
10.8\end{array}$ & $(-)$ \\
\hline 'Murfatlar' & $\begin{array}{l}\text { noninfected } \\
\text { infected }\end{array}$ & $\begin{array}{l}36.9 \\
41.8\end{array}$ & $(-)^{*}$ & $\begin{array}{l}2.4 \\
2.6\end{array}$ & $(-)$ & $\begin{array}{l}0.69 \\
0.73\end{array}$ & $(-)$ & $\begin{array}{l}40.5 \\
44.4\end{array}$ & $(-)^{* *}$ & $\begin{array}{l}26.7 \\
28.1\end{array}$ & $(-)^{* *}$ & $\begin{array}{l}40.0 \\
42.5\end{array}$ & $(-)^{* *}$ & $\begin{array}{l}20.5 \\
21.1\end{array}$ & $(-)$ & $\begin{array}{l}36.0 \\
39.2\end{array}$ & $(-)^{* *}$ & $\begin{array}{l}10.3 \\
10.4\end{array}$ & $(-)$ \\
\hline ‘Olimp’ & $\begin{array}{l}\text { noninfected } \\
\text { infected }\end{array}$ & $\begin{array}{l}41.1 \\
46.3\end{array}$ & $(-)$ & $\begin{array}{l}2.8 \\
3.3\end{array}$ & $(-)^{*}$ & $\begin{array}{l}0.56 \\
0.95\end{array}$ & $(-)^{* *}$ & $\begin{array}{l}45.4 \\
47.4\end{array}$ & $(-)$ & $\begin{array}{l}28.9 \\
31.2\end{array}$ & $(-)^{* *}$ & $\begin{array}{l}42.1 \\
42.7\end{array}$ & $(-)$ & $\begin{array}{l}20.2 \\
21.6\end{array}$ & $(-)^{* *}$ & $\begin{array}{l}38.7 \\
38.3\end{array}$ & $(+)$ & $\begin{array}{l}10.4 \\
11.6\end{array}$ & $(-)^{* *}$ \\
\hline 'Palava' & $\begin{array}{c}\text { noninfected } \\
\text { infected }\end{array}$ & $\begin{array}{l}59.9 \\
59.9\end{array}$ & $\begin{array}{c}(+/- \\
)\end{array}$ & $\begin{array}{l}3.7 \\
3.9\end{array}$ & $(-)$ & $\begin{array}{l}1.11 \\
1.09\end{array}$ & $(+)$ & $\begin{array}{l}47.3 \\
47.6\end{array}$ & $(-)$ & $\begin{array}{l}28.9 \\
29.2\end{array}$ & $(-)$ & $\begin{array}{l}49.0 \\
50.1\end{array}$ & $(-)$ & $\begin{array}{l}20.8 \\
23.1\end{array}$ & $(-)^{* *}$ & $\begin{array}{l}44.6 \\
44.5\end{array}$ & $(+)$ & $\begin{array}{l}11.1 \\
11.2\end{array}$ & $(-)$ \\
\hline 'Poljus Južnyj' & $\begin{array}{l}\text { noninfected } \\
\text { infected }\end{array}$ & $\begin{array}{l}20.2 \\
21.7\end{array}$ & $(-)$ & $\begin{array}{l}2.4 \\
2.7\end{array}$ & $(-)$ & $\begin{array}{l}0.92 \\
0.95\end{array}$ & $(-)$ & $\begin{array}{l}33.5 \\
36.0\end{array}$ & $(-)^{* *}$ & $\begin{array}{l}24.7 \\
26.8\end{array}$ & $(-)^{* *}$ & $\begin{array}{l}31.3 \\
32.0\end{array}$ & $(-)$ & $\begin{array}{l}17.1 \\
18.0\end{array}$ & $(-)^{*}$ & $\begin{array}{l}30.3 \\
31.7\end{array}$ & $(-)$ & $\begin{array}{l}11.8 \\
11.8\end{array}$ & $(+)$ \\
\hline 'Saldcot' & $\begin{array}{l}\text { noninfected } \\
\text { infected }\end{array}$ & $\begin{array}{l}28.7 \\
27.6\end{array}$ & $(+)$ & $\begin{array}{l}2.4 \\
2.3\end{array}$ & $(+)$ & $\begin{array}{l}0.64 \\
0.71\end{array}$ & $(-)$ & $\begin{array}{l}37.9 \\
37.8\end{array}$ & $(+)$ & $\begin{array}{l}22.8 \\
24.8\end{array}$ & $(-)^{* *}$ & $\begin{array}{l}37.6 \\
35.7\end{array}$ & $(+)^{*}$ & $\begin{array}{l}18.7 \\
18.5\end{array}$ & $(+)$ & $\begin{array}{l}35.4 \\
35.1\end{array}$ & $(+)$ & $\begin{array}{l}11.4 \\
11.6\end{array}$ & $(-)$ \\
\hline 'Svatava' & $\begin{array}{l}\text { noninfected } \\
\text { infected }\end{array}$ & $\begin{array}{l}42.1 \\
41.5\end{array}$ & $(+)$ & $\begin{array}{l}3.7 \\
3.4\end{array}$ & $(+)$ & $\begin{array}{l}1.06 \\
1.14\end{array}$ & $(-)$ & $\begin{array}{l}40.2 \\
40.9\end{array}$ & $(-)$ & $\begin{array}{l}25.1 \\
26.9\end{array}$ & $(-)^{*}$ & $\begin{array}{l}42.8 \\
43.4\end{array}$ & $(-)$ & $\begin{array}{l}20.7 \\
20.3\end{array}$ & $(+)$ & $\begin{array}{l}40.2 \\
40.8\end{array}$ & $(-)$ & $\begin{array}{l}12.3 \\
11.7\end{array}$ & $(+)$ \\
\hline 'Vardaguin Vag.' & $\begin{array}{l}\text { noninfected } \\
\text { infected }\end{array}$ & $\begin{array}{l}49.6 \\
51.0\end{array}$ & $(-)$ & $\begin{array}{l}2.4 \\
2.3\end{array}$ & $(+)$ & $\begin{array}{l}0.75 \\
0.79\end{array}$ & $(-)$ & $\begin{array}{l}46.1 \\
46.6\end{array}$ & $(-)$ & $\begin{array}{l}29.6 \\
29.1\end{array}$ & $(+)$ & $\begin{array}{l}41.3 \\
42.0\end{array}$ & $(-)$ & $\begin{array}{l}17.3 \\
16.8\end{array}$ & $(+)$ & $\begin{array}{l}40.9 \\
41.3\end{array}$ & $(-)$ & $\begin{array}{l}11.2 \\
10.9\end{array}$ & $(+)$ \\
\hline 'Veselka' & $\begin{array}{l}\text { noninfected } \\
\text { infected }\end{array}$ & $\begin{array}{l}62.0 \\
36.4\end{array}$ & $(+)^{* *}$ & $\begin{array}{l}4.0 \\
3.0\end{array}$ & $(+)^{* *}$ & $\begin{array}{l}1.43 \\
0.95\end{array}$ & $(+)^{* *}$ & $\begin{array}{l}47.7 \\
40.9\end{array}$ & $(+)^{* *}$ & $\begin{array}{l}31.0 \\
27.1\end{array}$ & $(+)^{* *}$ & $\begin{array}{l}47.7 \\
39.0\end{array}$ & $(+)^{* *}$ & $\begin{array}{l}23.5 \\
21.1\end{array}$ & $(+)^{* *}$ & $\begin{array}{l}45.7 \\
37.3\end{array}$ & $(+)^{* *}$ & $\begin{array}{l}12.5 \\
11.6\end{array}$ & $(+)^{*}$ \\
\hline 'Vestar' & $\begin{array}{l}\text { noninfected } \\
\text { infected }\end{array}$ & $\begin{array}{l}44.5 \\
33.5\end{array}$ & $(+)^{* *}$ & $\begin{array}{l}3.2 \\
2.6\end{array}$ & $(+)^{* *}$ & $\begin{array}{l}0.98 \\
0.75\end{array}$ & $(+)^{* *}$ & $\begin{array}{l}41.9 \\
38.7\end{array}$ & $(+)^{* *}$ & $\begin{array}{l}23.6 \\
22.6\end{array}$ & $(+)^{*}$ & $\begin{array}{l}43.0 \\
38.5\end{array}$ & $(+)^{* *}$ & $\begin{array}{l}21.3 \\
19.1\end{array}$ & $(+)^{* *}$ & $\begin{array}{l}40.4 \\
36.7\end{array}$ & $(+)^{* *}$ & $\begin{array}{l}13.0 \\
11.9\end{array}$ & $(+)^{* *}$ \\
\hline Average value & $\begin{array}{c}\text { noninfected } \\
\text { infected }\end{array}$ & $\begin{array}{l}43.5 \\
39.3\end{array}$ & $(+)$ & $\begin{array}{l}2.9 \\
2.8\end{array}$ & $(+)$ & $\begin{array}{l}0.87 \\
0.82\end{array}$ & $(+)^{* *}$ & $\begin{array}{l}42.2 \\
41.6\end{array}$ & $(+)$ & $\begin{array}{l}26.6 \\
26.5\end{array}$ & $(+)$ & $\begin{array}{l}42.0 \\
40.1\end{array}$ & $(+)^{* *}$ & $\begin{array}{l}20.0 \\
19.6\end{array}$ & $(+)^{* *}$ & $\begin{array}{l}39.8 \\
38.2\end{array}$ & $(+)$ & $\begin{array}{l}11.5 \\
11.1\end{array}$ & $(+)$ \\
\hline
\end{tabular}


Table 4. Result of nested PCR detection of phytoplasma ESFY in different plant organs from apricots (data from 2008-2014)

\begin{tabular}{cccc}
\hline $\begin{array}{c}\text { Tree } \\
\text { organs }\end{array}$ & $\begin{array}{c}\text { Number of phytoplasma } \\
\text { positive samples }\end{array}$ & $\begin{array}{c}\text { Number of phytoplasma } \\
\text { negative samples }\end{array}$ & $\begin{array}{c}\text { Average of positive detection } \\
(\%)\end{array}$ \\
\hline Peduncle & 59 & 25 & 70.2 \\
Pistil & 0 & 84 & 0 \\
Stamen & 0 & 84 & 0 \\
Pollen & 0 & 84 & 0 \\
Fruit flesh & 37 & 51 & 42.0 \\
Kernel & 22 & 62 & 26.2 \\
Cotyledons & 0 & 84 & 0 \\
Young sprouts & 0 & 84 & 0 \\
\hline Total & $\mathbf{1 1 8}$ & $\mathbf{5 5 8}$ & $\mathbf{2 1 . 1 5}$ \\
\hline
\end{tabular}

\section{Discussion}

Results of this study showed negative effects of ESFY phytoplasma on pomological quantitative traits (fruit, stone and kernel weight, fruit and stone dimensions, and fruit set) whereas the fruit shape was also affected, indicating lower yield of flatter and smaller fruits from infected trees. Interestingly, the content of soluble solids of fruits from infected trees was higher than from noninfected trees. However, only the fruit set, index of fruit shape, soluble solids content, kernel weight and fruit and stone width of infected trees were significantly different from noninfected trees, of which the phytoplasma ESFY showed the strongest influence on the decrease of fruit set. The fruit set is an important economic indicator of the training system effectiveness, quality of the variety, and the health of the orchard, and is substantial for high yield. Interestingly, in analysis of the influence of phytoplasma ESFY on pomological traits by variety, higher, but also lower values of pomological traits were recorded in infected trees when compared to noninfected trees of respective varieties, showing inconsistent response of varieties to infection by phytoplasma ESFY.

A similar inconsistency was observed in evaluation of phenophases (blooming time and ripening) where infected trees of some varieties were blooming and ripening earlier but also later than noninfected trees. Late blooming of infected trees is a common symptom of ESFY phytoplasma infection (Chabrolin, 1924; Morvan, 1977), however no information is available in the case of earlier blooming of infected trees.

Significant differences in fruit dimensions between infected and noninfected trees of some varieties (e.g. 'Arzami Arom.', 'Bergeron', 'Hargrand', 'Hatif Col.', 'Veselka') could be explained by higher or lower fruit set, where at higher fruit set the size of the fruit is often smaller. However, only at the variety 'Bergeron' the relation of the higher fruit set to lower fruit dimensions was observed, whereas in the case of varieties 'Arzami Arom.', 'Hargrand', 'Hatif Col.' and 'Veselka', the noninfected trees had higher fruit sets of bigger fruits, and the infected trees of the same varieties had opposite results.

Comparing the presented results with those of the study by Gazel et al. (2009), similar results were observed in the fruit set and fruit and stone weight which were overall negatively influenced by phytoplasma in both studies. However, in the present study, the soluble solids content of fruits from infected trees was higher than from noninfected trees, which is not in agreement with the results of Gazel et al. (2009). Moreover in the present study in some varieties, both positive and negative influences of phytoplasma ESFY on analysed traits were observed, whereas in Gazel et al. (2009) only negative influences of phytoplasma ESFY regardless on the variety were observed. These differences could be explained by the substantially lower tested set of a total of three infected trees in the work of Gazel et al. (2009), while in presented study 16 genotypes (a total of 32 trees/ 16 noninfected and 16 infected) were studied.

One of the most negatively influenced traits by the phytoplasma ESFY, next to the fruit set, was the pollen germination. Only varieties 'Bergeron' and 'Lemeda' showed slightly higher pollen germination in infected trees when compared to noninfected trees. High values of pollen germinations are important for successful pollination and subsequent fruit set and yield. Although the fruit set was negatively affected by phytoplasma ESFY in the present study, there is a low probability that the majority of trees of any orchard would be infected by phytoplasma causing lower yields by way of decreased pollen germination.

When taking in account that the seed viability of some varieties was higher in infected trees and that the phytoplasma ESFY was detected in $26.2 \%$ of the milky kernels, then the seed germination might be negatively affected, considering that phytoplasma ESFY was not detected in seedlings from infected trees. Based on this observation the seed viability does not give a comprehensive overview of the influence of phytoplasma on production of seedlings from infected trees. Focus should be directed to the seed germination, which was not evaluated in this study. However, it is not known, whether all infected seeds do not germinate, which, would then result in lower seed germination, or natural recovery is occurring during germination of infected seeds. Based on the results of Cordova et al. (2003), where lethal yellowing phytoplasma was studied on coconut embryos, it is more likely, that the infected seeds do not germinate although, the seeds are viable.

In the present study, the recorded seed viability of infected trees of some varieties was lower, but also higher, than of noninfected trees, which does not correspond with the results of a one-year study by Nečas et al. (2008), where all the analysed infected trees had lower seed viability compared to noninfected trees. This difference in results could be caused by higher influence of exogenous factors (e.g. weather) on the result between one-year and presented seven-year study, which is partly eliminated in long term studies. 
The above mentioned inconsistent behaviour of phytoplasma infected trees of some varieties in studied pomological traits and phenophases can be explained by the influence of the host genotype on the phytoplasmal infection and subsequent symptom manifestation. This statement is proved by the results of the present study, where infected trees of varieties 'Arzami Arom.', 'Hatif Col.', 'Veselka' and 'Vestar' were in almost every analysed traits significantly different than noninfected trees, suggesting higher sensitivity of these varieties to phytoplasma ESFY infection. On the other hand, the infected tree of variety 'Churmai', was in all traits nonsignificantly different than the noninfected tree, suggesting higher tolerance to phytoplasma ESFY. However, the influence of the composition of bacteria and fungi inside the tree, which has been studied intensively recently (Hardoim et al., 2015) or of different phytoplasma ESFY strains (Danet et al., 2011) cannot be ruled out. Finally, to be able to draw more generalized result in studied traits, a much larger apricot orchard should be analysed.

The results of detection of phytoplasma ESFY in generative organs and seedlings show clearly that phytoplasma is not transmitted by seeds, nor pollen, which is in agreement with the results of Nečas et al. (2008). Interestingly, samples of pistil, stamen and pollen were negative for the presence of phytoplasma, which was, however, later detected in soft milky kernels and fruit flesh. Possible ways of phytoplasma transfer into kernels and fruit flesh could be through vascular system of peduncle during fruit development.

\section{Conclusions}

From the analyses of traits between infected and noninfected trees it can be concluded that none of the traits were significantly affected by phytoplasma ESFY in all of the tested varieties, although overall significant differences were observed between infected and noninfected trees. On the level of varieties, in all analysed traits, both positive and negative influences of phytoplasma ESFY were observed when compared to noninfected trees. There might be possible influence of the host genotype on phytoplasmal infection and symptom manifestation which should to be studied in future researches. The most negatively influenced traits by phytoplasma ESFY were the fruit set and pollen germination. Finally, phytoplasma ESFY is not transmitted by pollen nor by seeds, even though the phytoplasma was detected in milky kernels and flesh of immature fruits.

\section{Acknowledgements}

This result was particularly obtained with the support of project NAZV/KUS QJ1510352 funded by Ministry of Agriculture of the Czech Republic.

\section{References}

Ahrens U, Seemüller E (1992). Detection of DNA of plant pathogenic mycoplasmalike organisms by a polymerase chain reaction that amplifies asequence of the $16 \mathrm{~S}$ rRNA gene. Phytopathology 82:828-832.
Ahrens U, Lorenz KH, Seemüller E (1993). Genetic diversity among mycoplasmalike organisms associated with stone fruit diseases. Molecular Plant-MicrobeInteractions 6:686-691.

Bertaccini A, Paltrinieri S, Caprara L, Laimer M, Hanzer V, Balla I (2004). Improved molecular methods for detection of European stone fruit yellows (ESFY) phytoplasmas from in-vitro shoots of fruit trees. Acta Horticulturae 657:495-500.

Carraro L, Osler R, Loi N, Ermacora P, Refatti E (1998). Transmission of European stone fruit yellows phytoplasma by $\mathrm{Ca}$. prini. Journal of Phytopathology 80:233-239.

Carraro L, Ferrini F, Ermacora P, Loi N (2002). Role of wild Prunus species in the epidemiology of European stone fruit yellows. Plant Pathology 51(4):513-517.

Cordova I,Jones P, Harrison NA, Oropeza C (2003). In situ PCR detection of phytoplasma DNA in embryos from coconut palms with lethal yellowing disease. Molecular Plant Pathology 4(2):99-108.

Danet JL, Balakishiyeva G, Cimerman A, Sauvion N, Marie-Jeanne V, Labonne G, ... Foissac X (2001). Multilocus sequence analysis reveals the genetic diversity of European fruit tree phytoplasmas and supports the existence of inter-species recombination. Microbiology 157(2):438450.

Deng S, Hiruki C (1991). Amplification of 16S rRNA genes from culturable and nonculturable Mollicutes. Journal of Microbiology Methods 14:53-61.

Gazel M, Caglayan K, Serce CU, Son L (2009). Evaluations of apricot trees infected by 'Candidatus Phytoplasma prunorum' for horticultural characteristics. Romanian Biotechnological Letters 14(1):4123-4129.

Gibb KS, Padovan AC (1994). A DNA extraction method that allows reliable PCR amplification of MLO DNA from 'difficult' plant host species. Genome Research 4(1):56-58.

Hardoim PR, Van Overbeek LS, Berg G, Pirttilä AM, Compant S, Campisano A, ... Sessitsch A (2015). The hidden world within plants: ecological and evolutionary considerations for defining functioning of microbial endophytes. Microbiology and Molecular Biology Reviews 79(3):293-320.

Chabrolin C (1924) Quelques maladies des arbres fruitiers de la Vallée du Rhône. Annales Epiphytes 10:265-333.

Jarausch W, Lansac M, Saillard C, Broquaire JM, Dosba F (1998). PCR Assay for specific detection of European stone fruit yellows phytoplasmas and its use for epidemiological studies in France. European Journal of Plant Pathology 104:17-27.

Jarausch W, Lansac M, Dosba F (1999). Seasonal colonization pattern of European stone fruit yellows phytoplasmas in different Prunus species detected by specific PCR Journal of Phytopathology 147(1):47-54.

Jarausch W, EyquardJP, LansacM, Mohns M, DosbaF (2000). Susceptibility and tolerance of new French Prunus domestica cultivars to European stone fruit yellows phytoplasmas. Journal of Phytopathology 148(7-8):489-493.

Kison H,SeemüllerE (2001). Differences in strain virulence of the European Stone Fruit Yellows Phytoplasma and susceptibility of stone fruit trees on various rootstocks to this pathogen. Journal of Phytopathology 149:533-541. 
114

Lakon G (1949). The topographical tetrazolium method for determining the germinating capacity of seeds. Plant Physiology 24(3):389-394.

Lee IM, Davis RE, Hiruki C (1991). Genetic Interrelatedness among Clover Proliferation Mycoplasmalike Organism (MLOs) and Other MLOs investigated by nucleic acid hybridization and Restriction Fragment Length Polymorphism Analyses. Applied and Environmental Microbiology 57(12):3565-3569.

Lee IM, Gundersen RDE, Davis RE, Bartoszyk IM (1998). Revised classification scheme of phytoplasmas based on RFLP analyses of $16 \mathrm{Sr}$ RNA and ribosomal protein gene sequences. International Journal of Systematic and Evolutionary Microbiology 48(4):1153-1169.

Lorenz KH, Schneider B, Ahrens U, Seemüller E (1995). Detection of the apple proliferation and pear decline phytoplasmas by PCR amplification of ribosomal and nonribosomal DNA. Phytopathology 85:771-776.

MarconeC, SeemüllerE(2001). A chromosome map of the European stone fruit yellows phytoplasma. Microbiology 147(Pt5):1213-1221.

Morvan G (1977). Apricot chlorotic leafroll. Bulletin OEPP/EPPO 7:3755.

Nečas T, Mašková V, Krška B (2008). The possibility of ESFY phytoplasma transmission through flowers and seeds. Acta Horticulturae 781:443447.

Nečas T, Ondrášek I, Krška B (2015). 'Candidatus Phytoplasma prunorum' a pathogen spreading uncontrollably in apricot orchards in the Czech Republic. Acta Horticulturae 1105:131-136.

Nitranský Š (1992). Descriptor list genus Armeniaca P. MILL. Genové zdroječ. 58. SEMEXŠP Bratislava, VÚRV Praha-Ruzyně.

Pastore M, Piccirillo P, Tian J, Simeone AM, Paltrinieri S, Bertaccini A (2001). Transmission by patch grafting ofESFY phytoplasma to apricot (Prunus armeniaca L.) and Japanese plum (Prunus salicina Lindl). Acta Horticulturae 550:339-344.

Schneider B, Seemüller E, Smart CD, Kirkpatrick BC (1995). Phylogenetic classification of plant pathogenic mycoplasma-like organisms or phytoplasmas. In Razin S, Tully JG (Eds). San Diego, CA: Molecular and Diagnostic Procedures in Mycoplasmology. Academic Press 1:369380.
Seemüller E (1976). Investigations to demonstrate mycoplasma-like organism in diseased plants by fluorescence microscopy. Acta Horticulturae 67:109-112.

Seemüller E, Schneider B (2004). 'Candidatus Phytoplasma mali', 'Candidatus Phytoplasma pyri' and 'Candidatus Phytoplasma prunorum', the causal agents of apple proliferation, pear decline and European stone fruit yellows, respectively. International Journal of Systematic and Evolutionary Microbiology 54(4):1217-1226.

Sertkaya G, Martini M, Ermacora P, Musetti R, Osler R (2005). Detection and characterization of phytoplasmas in diseased stone fruits and pear by PCR-RFLP analysis in Turkey. Phytoparasitica 33(4):380-290.

Ulubaş Serçe Ç, Gazel M, Yalçin S, Çağlayan K (2007). Responses of six Turkish apricot cultivars to ‘Candidatus phytoplasma prunorum' under greenhouse conditions. Bulletin of Insectology 60 (2):309-310.

Tanaka T, Wimol S, Mizutani T (1995). Inheritance of fruit shape and seed size of watermelon (Citrullus lanatus). Journal of the Japanese Society for Horticultural Science 64(3):543-548.

Thébaud G, Sauvion N, Chadoeuf J, Dufils A, Labonne G (2006). Identifying risk factors for European Stone Fruit Yellows from a Survey. Phytopathology 96(8):890-899.

Thébaud G, Yvon M, Alary R, Sauvion NL(2009). Efficient transmission of 'Candidatus phytoplasma prunorum' is delayed by eight months due to a long latency in its host-alternating vector. Phytopathology 99(3):265273.

Vachůn Z, Řezníček V (1989). Ovocnictví. Praktická cvičení II. Skriptum, VŠZv Brně. 